\title{
Medier og selvstændighed i Grønland
}

Signe Ravn-Højgaard, adjunkt med ph.d-forløb ved Ilisimatusarfik, Grønlands Universitet

Denne artikel diskuterer, hvad grønlandsk selvstondighed vil kunne tonkes at betyde for mediesystemet $i$ Grønland, samt hvilke tiltag, der kan vore nødvendige for storke grønlandske medier i fremtiden. Først beskrives mediesystemet $i$ Grønland ved hjoelp af Manuel Puppis' (2009) teori om sartrcek ved mediesystemer $i$ små stater. Det ses, at det grønlandske mediesystem er opbygget ud fra en målscetning, hvor medierne skal understøtte det grønlandske samfund ved at vore uafhongige og mangfoldige, styrke det grønlandske sprog og levere kvalitetsjournalistik, der kan løfte samfundsdebatten. Det grønlandske mediesystem er småt og sårbart over for bl.a. globale tendenser, der medfører, at traditionelle medier mister brugere og annonceindtjening til digitale platforme som Facebook og streaming-tjenester. Artiklen argumenterer for, at mediernes sårbarhed bliver større, hvis Grønlands selvstcendighed medfører strammere offentlig økonomi, hvilket kan gøre det svoerere for dem at udfylde deres funktion i samfundet. En interventionistisk medieregulering kan derfor vare en forudsatning for storke grønlandske medier, der kan udgøre en samlende og nationsopbyggende institution.

Indledning

I Grønland findes to landsdækkende mediehuse. Public service-stationen Kalaallit Nunaata Radioa (KNR), der producerer radio, TV og webnyheder, samt mediehuset Sermitsiaq.AG, der udgiver to ugentlige aviser - Sermitsiaq og AG - webnyheder, et par magasiner samt den husstandsomdelte gratisavis, Nuuk Ugeavis. Der findes lokalaviser, lokal-tv og lokalradio i adskillige byer - ofte drevet på frivillig basis og oftest uden egenproduceret journalistisk indhold (se en oversigt i Hussain, 2018). Derudover leverer et par hjemmesider med varierende frekvens ikke-redaktionelle nyheder om Grønland ved blandt andet at videreformidle pressemeddelelser. Selvom det grønlandske medieudbud er småt, har Grønland det højeste forbrug af national radio og tv i Norden (Ravn-Højgaard 2018b). Næsten alt skriftligt medieindhold udkommer både på grønlandsk og dansk, mens størstedelen af tv- og radioindholdet produceres udelukkende på grønlandsk (med nyhedsudsendelser på begge sprog som væsentligste undtagelse).

Da medierne udgør en central institution i demokratiet og spiller en vigtig rolle $\mathrm{i}$ nation building-processer (Anderson 1983; Louw 2005), er det en relevant institution at se nærmere på, når man taler om selvstændighed. Naimah Hussain (2017, udkommer 2019) har vist, at det grønlandske mediesystem i dag er tæt forbundet til det danske i kraft 
af f.eks. rekruttering af danske journalister, dansk-inspireret medielovning, og hyppig brug af danske kilder og citering af danske medier. Journalistuddannelsen blev bygget efter dansk forbillede. Hussain viser, hvordan der i kraft af denne orientering mod danske medier, herfra adopteres idealer om, hvad god journalistik er. Det er ikke et bevidst valg, men noget, der "tvært imod virker helt naturligt indlejret i de daglige rutiner, og samtidig har dybe historiske rødder, der handler om den historisk tætte relation mellem de to lande" (Hussain, udkommer 2019).

Selvstændighedsønsket i dag handler, ifølge Kirsten Thisted, dybest set om "at gøre grønlænderne til eget referencepunkt" (2018). Man kunne derfor forestille sig, at en selvstændighedsproces kan medføre et politisk ønske om at etablere en særegen grønlandsk journalistisk praksis og idealer, som bevidst ikke orienterer sig mod Danmark. Sådanne ændringer vil i højere grad bero på den politiske motivation bag selvstændighed end være en følge af selvstændighed, da ændringerne af f.eks. medielovgivningen er mulige inden for selvstyrelovens rammer.

Den politiske motivation for selvstændighed vil selvfølgelig også få stor betydning for, hvordan et uafhængigt Grønland - såvel som dets medier - vil se ud. Det gør i høj grad diskussionen om medierne i et selvstændigt Grønland til et politisk spørgsmål, ikke mindst da det offentlige, som det vil blive diskuteret senere, spiller en stor rolle i at opretholde mediesystemet, som det ser ud i dag.

Da det er svært at forudsige, hvordan det - på et ikke nærmere defineret tidspunkt - fra politisk hold ønskes at medierne skal se ud, fokuserer denne artikel, hvad snarlig selvstændighed kan tænkes at få af konsekvenser for medielandskabet, som det ser ud i dag. Dette gøres, dels da foreløbige resultater fra en survey-undersøgelse foretaget af Greenland Perspective viser, at halvdelen af befolkningen ønsker selvstændighed om 18 år (i 2037) eller tidligere (Agneman og Minor 2018); og dels da det er svært at forudsige, hvordan medielandskabet vil se ud om 50 år. Det er ikke relevant at diskutere mediestøtte til printmedier i et selvstændigt Grønland, hvis printmedier ikke eksisterer til den tid.

Artiklen vil først undersøge mediesystemets nuværende strukturelle indretning i Grønland. Ved hjælp af Manuel Puppis' (2009) teori om medier i småstater analyseres det grønlandske mediesystem. Gennem tekstanalyse af officielle mediepolitiske dokumenter, kortlægges den rolle medierne tilskrives i samfundet som værende uafhængige, mangfoldige, sprog- og kulturbevarende samt leverandører af kvalitetsjournalistik, der kan kvalificere samfundsdebatten. Herefter diskuteres, hvad en eventuel grønlandsk selvstændighed vil betyde for mediernes evne til at varetage disse funktioner.

Teori: Mediesystemer i små stater

Det er relevant først at undersøge det nuværende grønlandske mediesystems karakteristika, for at sige noget om, hvordan det grønlandske mediesystem vil udvikle sig, hvis Grønland bliver selvstændigt. Selve mediesystem-begrebet kommer fra sociologisk felt- 
teori. Med et institutionelt makroperspektiv beskriver teorien relationen mellem det politiske system og medierne. Teorien forstår mediesystemer som en række strukturelle faktorer og institutioner, som interagerer og former hinanden - såsom mediemarkedet og statens rolle heri (se eksempelvis Hallin og Mancini 2004).

Manuel Puppis (2009) tilpasser Daniel C. Hallin og Paolo Mancinis' (2004) mediesystem-teori til små stater ved at argumentere for, at mediesystemets størrelse har betydning for dets strukturelle udformning. Selvom Puppis undersøger selvstændige stater, kan teorien også anvendes på Grønland, fordi det grønlandske mediesystem har en høj grad af autonomi fra det danske mediesystem med egne grønlandske medier og mediepolitik $\mathrm{mv}^{1}$. Puppis identificerer disse fire strukturelle særtræk ved mediesystemer i småstater:

1. Mangel på ressourcer: Medier i små stater har begrænset kapital, knowhow, journalister mv.

2. Få reklameindtæegter: Mens det stort set koster det samme at producere medieindhold til små og store mediemarkeder, er der ikke mange penge at tjene på reklamer i små mediemarkeder.

3. Påvirkninger udefra: Små mediemarkeder bliver i høj grad påvirket af fænomener som globalisering og kommercialisering og er nødt til at tilpasse sig. På samme måde bliver små mediesystemer også påvirket af politiske beslutninger i store nabolande og må tilpasse sig.

4. Sårbarhed: Små mediesystemer er særligt sårbare over for udenlandske medieprodukter, der kan udkonkurrere lokale medieprodukter.

Disse strukturelle vilkår fører ofte til, at små stater har en aktiv mediepolitik, argumenterer Puppis. For at beskytte lokale medier og fremme en mangfoldighed i medieudbuddet, der ikke ville være muligt på markedsvilkår alene, vil små stater ofte føre en interventionistisk mediepolitik med for eksempel mediestøtte (Puppis, 2009).

\section{Det grønlandske mikro-mediesystem}

I Grønland gælder Puppis' pointer om, at mediesystemet er kendetegnet ved få ressourcer, der dels gør det svært at opnå stordriftsfordele, når mediemarkedet er så småt; dels er der få medieprofessionelle og derfor mangel på specialiseret viden. Der er f.eks. kun ca. 35 fuldtidsjournalister (Hussain 2017) til at producere alle journalistiske produkter fra

\footnotetext{
${ }^{1}$ Selvom der er træk ved det grønlandske mediesystem, der er influeret af Danmark, som f.eks. den DRinspirerede public service-kontrakt, danskinspireret medielovgivning (hvilket der vendes tilbage til. Se Hussain, 2017 og 2019).
} 
kulturprogrammer til undersøgende erhvervsjournalistik. Til sammenligning er der 7.196 arbejdende journalister i Danmark (Skovsgaard og Dalen 2017).

Med blot 56.000 indbyggere udgør Grønland et meget lille medie- og reklamemarked. Det giver svære kår for reklame- og oplagsfinansierede medier, da omkostningerne ved medieproduktion er næsten uændrede uanset mediemarkedets størrelse.

Medierne har yderligere store omkostninger forbundet med oversættelse, da en stor del af medieindholdet udarbejdes både på grønlandsk og dansk. Derudover gør infrastrukturen det kostbart at distribuere medieindhold.

Endelig er Grønland kendetegnet ved store offentligt ejede virksomheder med monopol inden for deres virksomhedsområde, hvilket kan betyde færre potentielle annonceindtægter end på et konkurrencepræget marked, da man kan forestille sig, at en virksomhed uden konkurrenter, ikke har samme incitament for at annoncere i sammenligning med virksomheder på et konkurrencepræget marked.

Også Puppis’ tese om at små mediesystemer i høj grad påvirkes udefra gælder for det grønlandske mediesystem. Den teknologiske udvikling og globaliseringen gør, at det beskedne udbud af lokalt medieindhold i Grønland i stigende grad skal kæmpe om befolkningens opmærksomhed side om side med en ubegrænset mængde af udenlandske produktioner med større budgetter og flere ressourcer til rådighed, end de grønlandske medier har. Det medfører, at de grønlandske medier mister brugere og annonceindtægter til udenlandske virksomheder som f.eks. Facebook og Google (se f.eks. Newman et al. 2018 om disse globale tendenser). Det sker allerede i nogen grad i dag, selvom det løbende er lykkedes Sermitsiaq.AG at øge deres annonceindtægter på internettet (Deloitte 2018).

Ændrede medievaner kan også indvirke positivt på det grønlandske demokrati. F.eks. giver sociale medier nye muligheder for repræsentation samt debat og deling af information borgere imellem. I dag er Grønlands befolkning en af verdens mest aktive på Facebook (Nordlund 2016; Sermitsiaq 2018), men annoncekronerne som er knyttet til aktivitet på Facebook, går ikke til det grønlandske mediemarked. Danmarks Radios kanaler sendes ud til alle husstande sammen med KNR. Derudover kan man købe adgang til satellit-tv (via egen parabol eller tv-foreninger). Sammenlignet med de andre nordiske lande, har Grønland det største forbrug af national public service-tv. Det til trods for, at KNR er den nordiske public service-kanal, der udsender færrest timer fjernsyn, men altså samtidigt også er den eneste kanal, der sender på grønlandsk (Ravn-Højgaard 2018b). Befolkningen brugte i 2018, 58\% af tiden foran fjernsynet på at se KNR (KNR 2018b).

Grønland er påvirket mindre af globaliseringen og er derfor mindre sårbar end andre lande. Internettet generelt - herunder streaming-tjenester - bliver ikke anvendt lige så meget af den grønlandske befolkning i sammenligning med de andre nordiske lande (Ravn-Højgaard 2018b). En væsentlig årsag til dette er høje internetpriser, hvor det billigste abonnement, som giver mulighed for at streame uhindret koster $1099 \mathrm{kr}$. månedligt (februar 2019, 10/2 mbit (Tele-Post 2019)). Dette abonnement kan købes steder, hvor $82 \%$ af befolkningen bor. Resten af befolkningen må nøjes med abonnementer med lavere 
hastigheder samt forbrugsloft. For mobilt internet er priserne højere (se www.tusass.g1 for en prisliste).

Før åbningen af søkabel-forlængelsen og den forstærkede radiokæde mellem Nuuk og Upernavik i december 2017/oktober 2018, var det kun muligt for 37\% af befolkningen at købe abonnementer, som er hurtige nok til streaming (Tele-Post 2017, 2018). Disse infrastrukturudvidelser har øget internetbrugen markant. Som eksempel på dette udtalte Tele-Posts direktør, Kristian Reinert Davidsen, til Sermitsiaq.AG den 8. februar 2019 om internetforbruget i Nordgrønland: "[...] efter søkablet kom til, er trafikken nærmest eksploderet, så den i dag er fem gange så stor som for et år siden" (Turnowsky 2019a).

Denne 'eksplosion' i internettrafikken efter internettilgængeligheden blev øget, kan ses som en indikation på, at internetbrugen reelt er betinget af teleinfrastrukturen og af prissætningen. Det betyder, at politiske op- eller nedprioriteringer af teleinfrastrukturen og prissætningen vil påvirke internetbrugen. Når Naalakkersuisut (den grønlandske regering) vil trække 250 mio. kr. i udbytte ud af det selvstyrejede Tele-Post ${ }^{2}$ over de kommende tre år - foruden 137 mio. kroner i 2017 (Schultz-Nielsen 2017; Bestyrelsessekretariat 2018; Elkjær 2018) - vil det med stor sandsynlighed betyde højere priser og/eller langsommere internet, end man ellers kunne have fået. Det vil i relation til Puppis' teori om små mediesystemer betyde, at mediesystemet er mindre sårbart på grund af mindre påvirkning udefra; f.eks. i form af mindre streaming af udenlandske tvserier. Eller sagt med andre ord: de grønlandske medier har bedre vilkår så længe befolkningen - eller i hvert fald dele af den - ikke har alternativer i form af streaming.

\section{Mediepolitik}

Et andet karakteristika ved små mediesystemer er ifølge Puppis, at de er tilbøjelige til at føre en interventionistisk mediepolitik, hvor staten aktivt går ind og regulerer medierne. Baggrunden herfor er, at i små stater betragtes mediernes funktion nemlig oftere som kulturel og demokratisk snarere end som en ren kommerciel funktion. Det bliver derfor statens rolle at sikre mediernes eksistens, da det ikke kan klares af markedet alene i små stater (Puppis 2009).

Det er også tilfældet for Grønland i dag, hvor mediesystemet er opbygget ud fra en publicistisk tankegang. Mediehuset Sermitsiaq.AG er en erhvervsdrivende fond, der ikke har til formål at tjene penge til ejerne, men at udgive landsdækkende tosprogede medier, hvori der "gives en alsidig orientering og formidles og skabes debat om samfundsmæssige forhold" (Erhvervsstyrelsen 2019).

KNR er en public service-station, der får størstedelen af sine midler fra landskassen. Tilskuddet fra Selvstyret var i 2017 på 68 mio. kr. Derudover kommer reklameindtægter på

\footnotetext{
2 Tele-Post er et $100 \%$ selvstyreejet aktieselskab. Tele-Post har monopol (koncession) samt forsyningspligt på post, telefoni og stort set alle internetinfrastruktur og -tjenester (se f.eks. Telestyrelsen, 2014)
} 
5,6 mio. kr. (KNR 2018a). Mediehuset Sermitsiaq.AG modtog i 2017 et driftstilskud fra Selvstyret på 1,5 millioner kroner og havde samme år et overskud på 5,5 mio. kr. og en samlet omsætning på 32 millioner kroner (Deloitte 2018). Derudover findes der støtte til lokalmedier.

For at kunne sige noget mere om hvilke mål, medierne skal understøtte, undersøges nu gennem tekstanalyse af centrale policy-dokumenter de mest centrale formål, der lægger til grund for mediepolitikken i Grønland.

De centrale dokumenter er identificeret som al den gældende lovgivning på medieområdet. Det er Inatsisartutlov om radio- og tv-virksomhed (2014), Intsisartutlov om medieansvar (2007), Inatsisartutlov om mediestøtte (2016) samt bemærkningerne til disse love. Derudover inddrages nyeste public service-kontrakt for KNR, gældende KNR-strategi og gældende regeringskoalitionsaftale for det nuværende Naalakkersuisut (2018).

Først og fremmest lægges der vægt på, at medierne er uafhcengige. Det er et krav, at et medie er uafhængigt af det offentlige og interesseorganisationer, herunder politiske partier, for at mediet kan modtage mediestøtte ( $\$ 2$ i Inatsisartutlov om mediestøtte 2016). Loven om KNR har indbygget en vis institutionel armslængde til politikkerne f.eks. $i$ form af, at KNR ledes af en bestyrelse, hvor størstedelen af medlemmerne ikke er politisk udpegede, og ingen må besidde et politisk valgt embede. Yderligere skal 4-årige public servicekontrakter ( $\$ 28$ i Inatsisartutlov om radio- og tv-virksomhed 2014) sætte et værn mod politisk indblanding i programindholdet i det daglige.

For det andet lægges der i grønlandsk mediepolitik vægt på, at medierne skal understøtte et mangfoldigt informations- og medieudbud, der afspejler forskellige holdninger, interesser og kulturer i samfundet. KNR er gennem public service-forpligtelserne forpligtet til at levere "en bred samfundsmæssig dækning af Grønland og således afspejle den mangfoldighed af kultur og livsopfattelser" ( $\$ 20$ i Inatsisartutlov om radio- og tvvirksomhed 2014). Tilsvarende er formålet med mediestøtten at skabe mangfoldighed i medieudbuddet (Bemærkninger til Lov om Mediestøtte 2016).

I mediepolitikken findes et ideal om, at kvalitetsjournalistik bør sikre den offentlige debat således, at valgmuligheder, begrundelser og konsekvenser er velbelyste i samfundsdebatten. Dette ideal kan f.eks. ses i KNR's vision, at "give et nuanceret og kritisk billede af nyheder og aktualitet i og omkring Grønland" (KNR 2015). I KNR's strategi for 2014-2017 står der, at "Vi skal sammen med den øvrige presse være samfundets vogter ved at udføre kritisk journalistik, belyse og oplyse om alle samfundsforhold" (KNR 2014). Den erhvervsdrivende fond Sermitsiaq.AG har til formål at give "en alsidig orientering og formidle og skabes debat om samfundsmæssige forhold" (Erhvervsstyrelsen 2019).

Endelig bliver medierne set som instrument til at styrke grønlandsk sprog og kultur. KNR beskriver i sin strategi for 2014-2017 sin rolle som en kulturbærende institution med "betydeligt medansvar for fastholdelse af den unikke grønlandske kulturarv og det grønlandske sprog." (KNR 2014). 
At medierne bør have en sprogbevarende funktion findes også udtrykt både i loven om mediestøtte (Inatsisartutlov om mediestøtte 2016) og loven, der regulerer KNR's virksomhed, pålægger KNR "gennem en aktiv sprogpolitik at medvirke til at bevare og udvikle det grønlandske sprog" ( $\$ 24$ i Inatsisartutlov om radio- og tv-virksomhed 2014).

Overordnet kan den grønlandske mediepolitik betegnes som publicistisk, idet medierne skal understøtte demokratiet. De fire vigtigste formål med den grønlandske mediepolitik er altså at understøtte medier, der er uafhængige, mangfoldige og som styrker det grønlandske sprog og kultur samt leverer kvalitetsjournalistik.

\section{Medier i et selvstændigt Grønland}

Artiklen har nu i overordnede træk beskrevet mediesystemet i Grønland i dag som et meget småt og derfor sårbart mediesystem, hvor Selvstyret spiller en stor rolle i at opretholde et medieudbud, der ikke ville kunne eksistere på markedsvilkår alene. Hvordan vil dette mediesystem blive påvirket, hvis Grønland erklæres selvstændigt?

Ovenfor blev det vist, at økonomi er en vigtig faktor for, hvordan fremtidens mediesystem kommer til at se ud. Der er imidlertid ikke enighed om, hvad den økonomiske effekt af selvstændighed vil være. Holdningen til dette spørgsmål i Grønland er - ifølge undersøgelsen fra Greenland Perspective - tæt korreleret med holdningen til, om selvstændighed er ønskeligt. Langt flere af dem, der ønsker selvstændighed, mener også, at Grønland vil have økonomisk gavn af selvstændighed, mens det forholder sig modsat for dem, der ikke ønsker selvstændighed.

Artiklen bygger på den antagelse, at selvstændighed i et nuværende scenarium vil medføre, at indtægterne til Selvstyret vil blive reduceret, i hvert fald på kort sigt, hvis bloktilskuddet fra Danmark ophører. Det kan medføre mindre købekraft til at købe aviser og annoncer. Derudover kan man forestille sig, at annonceindtægterne fra den danske stat vil forsvinde, da f.eks. jobannoncer indrykket af den danske stat, vil forsvinde i takt med, at statslige arbejdspladser i Grønland forsvinder. Det kan få stor betydning for de privatejede medier. Med dette in mente diskuteres nu, hvad selvstændighed vil kunne tænkes at betyde for mediernes evne til at opfylde de formål, som tidligere beskrevet, nemlig: mangfoldighed i udbud, kritisk journalistik, uafhængige medier og sprogbevarende medier.

\section{Uafhængige medier}

Selve begrebet 'uafhængige medier' tillægges forskellige betydninger i forskellige politiske systemer, mediesystemer og mediers selvforståelser. Kari Karppinen og Hallvard Moe (2016) påpeger, at uafhængighed både kan være fra det offentlige, fra annoncører, fra medieejere eller andre politiske og økonomiske interesser. Man kan derfor passende starte med at stille spørgsmålet: uafhængigt af hvad? 
Selvstyret spiller en stor rolle i det grønlandske mediesystem i dag, og derfor er særligt forholdet mellem medierne og Selvstyret relevant for en analyse af uafhængige medier i et selvstændigt Grønland. Særligt $i$ forhold til public service-medier tales der ofte om uafhængighed fra det offentlige, da public service-medier jo netop er ejet og finansieret af det offentlige (Karppinen and Moe 2016).

I Grønland vedrører diskussionen om mediernes økonomiske uafhængighed fra den offentlige sektor også de private medier, selvom private medier ofte skelner mellem uafhængige og frie medier på den ene side og offentligt ejede/regeringsmedier på den anden side (se f.eks. AG 2011; Schultz-Lorentzen 2011; Krarup 2017). Selvstyret ejer og finansierer KNR, mens det private mediehus Sermitsiaq.AG's medier primært finansieres via bladsalg og annonceindtægter. Alligevel kan dette skel virke paradoksalt, da den offentlige sektor med Selvstyret i spidsen er den vigtigste annoncør. Dermed er de private medier også økonomisk afhængige af den offentlige sektor. Dette paradoks kom f.eks. til udtryk, da bestyrelsesformand i Mediehuset Sermitsiag.AG, Jørgen Ejbøl, i 2011 udtalte, at "landets landsdækkende og uafhængige medier ikke i længden kan løfte sin samfundsopgave, hvis kommuner og Selvstyret ikke understøtter med blandt andet stillingsannoncer" (Schultz-Lorentzen 2011).

Det viser også, at økonomisk uafhængighed fra det offentlige er svært i det grønlandske mediesystem, hvor der er så få penge i mediemarkedet samtidigt med, at det offentlige spiller en stor rolle i det grønlandske samfund. Man kan dog ikke nødvendigvis slutte fra økonomisk afhængighed til redaktionel afhængighed.

Også spørgsmålet om journalisters og kilders uafhængighed er relevant i denne sammenhæng. Hussain viser, at der i det lille grønlandske samfund let opstår habilitetsproblemer, når f.eks. kilde og journalist kender hinanden privat eller kilden har flere hverv, der gør, at journalisten må sætte spørgsmålstegn ved kildens habilitet. Det begrænsede antal kilder inden for et givent område kan yderligere sætte journalisterne i et afhængighedsforhold, hvor der kan opstå en interessekonflikt mellem at skrive en kritisk historie og at bevare et godt forhold til kilden (se uddybende hos Hussain, udkommer 2019).

Samlet tyder dette på, at man i Grønland ikke kan tale om uafhængige medier på samme måde, som man kan i større mediesystemer. Hvis selvstændighed medfører dårligere medieøkonomi, risikerer de private medier i endnu højere grad at blive økonomisk afhængige af Selvstyret. Institutionel uafhængighed, hvor mekanismer i loven sørger for at opretholde en vis armslængde til det politiske system, kan være en måde at imødekomme dette problem (Karppinen og Moe 2016). Dette søges allerede i dag gennem bl.a. krav om, at mediestøttemodtagere ikke må være ejede af det offentlige, af interesseorganisationer eller af partier. Institutionel armslængde mellem det politiske system og KNR's indhold øges ved f.eks. at indsætte en politisk uafhængig bestyrelse (dog delvist udpeget af Naalakkersuisut).

Både i forhold til de private medier og KNR vil man kunne øge distancen mellem det politiske system og mediesystemet ved fra politisk side at forpligte sig til ikke plud- 
seligt at ændre mediernes rammebetingelser. Det kan f.eks. ske ved at gøre KNR's bevillinger flerårige, så de ikke som i dag skal forhandles hvert år i Inatsisartut (det grønlandske parlament). Dette er tidligere blevet kritiseret for at gøre KNR afhængige af det politiske system (Mediearbejdsgruppen 2010).

Armslængdeprincippet kan blive styrket ved, at man fra politisk side afstår fra at blande sig i KNR's indhold. I dag debatteres KNR's indhold med jævne mellemrum i Inatsisartut, når politikerne vil pålægge KNR at sende liveradio fra Inatsisartut-samlingerne (se f.eks. Walter Turnowsky 2019b vedr. seneste debat). Det har dog ikke medført, at KNR i dag sender liveradio fra Inatsisartut.

De private mediers uafhængighed kan styrkes ved, at det politiske system afstår fra pludselige ændringer i medieregulering. I 2015 blev mediestøtte-loven ændret fra at være en generel driftsstøtte til at blive en specifik projektstøtte (Selvstyrets bekendtgørelse om medietilskud 2015). Omlægningen fandt sted efter politisk tumult om Mediehuset Sermitsiaq.AG's støtte, og blev kritiseret heftigt af mediebranchen for at være et brud med armslængdeprincippet, idet et udvalg nedsat af Naalakkersuisut skulle vurdere ansøgninger om tilskud til afgrænsede medieprojekter (se f.eks. Dollerup-Scheibel 2015). AG kaldte omlægningen en politisk "hævnakt" for den kritiske journalistik om daværende formand for Naalakkersuisut, Aleqa Hammond (AG 2015). Året efter blev mediestøtten igen ændret således, at der nu uddeles driftsstøtte side om side med projektstøtte (Naalakkersuisut 2018). Projektstøtte efter denne ordning er dog ikke blevet uddelt.

En sådan skiftende politisk kurs kan skabe utryghed for medierne, da de kan frygte, at kritisk journalistik kan få politikkerne til pludselig at ændre vilkårene eller undlade at tildele støtte, hvilket kan medføre risiko for selvcensur.

I en eventuel situation med trangere medieøkonomi som følge af selvstændighed samt tendenser på mediemarkederne, hvor f.eks. annoncekronerne går til Facebook, kan dette blive mere problematisk. Man kan forestille sig, at medierne bliver mere afhængige af offentlige midler og dermed bliver endnu mere følsomme over for politisk indblanding.

De private mediers afhængighed af kommercielle interesser er bestemt også en relevant problemstilling. I en situation med stort pres på mediernes økonomi, kunne man forestille sig, at der kunne opstå konflikt mellem kritisk journalistik og vigtige annoncørers interesser. Denne problemstilling kan blive forstærket af den grønlandske kontekst, hvor der er få annoncører, hvilket gør tabet af én annoncør relativt mere mærkbart. Samtidigt er der få alternative medier til at skrive de kritiske historier i stedet. Tidligere har

dårlig økonomi tvunget Nanoq Media til at droppe deres daglige nyhedsudsendelser og fået Sermitsiaq og AG til at fusionere til ét mediehus.

\section{Mangfoldigt medieudbud}

Idealet om et mangfoldigt medieudbud er velbeskrevet $\mathrm{i}$ forskningslitteraturen og ses $\mathrm{i}$ mediepolitikker over hele verden. Mangfoldighed kan både være i formater, emner, holdninger, geografisk dækning mv. (McQuail 1992). Puppis et al. (2009) peger på, at det er 
vanskeligt at opnå et mangfoldigt medieudbud i et lille mediemarked uden regulerende mediepolitik. Ragnar Karlsson (2008) betegner det grønlandske medieudbud som imponerende stort, når man tager højde for befolkningstallet. Det alsidige udbud af formater er i sig selv en indikation på, at der findes mange forskelligartede kilder til information og oplysning om samfundsforhold i medierne. Det grønlandske medieindhold udbydes primært af de blot to landdækkende mediehuse. Så selvom to mediehuse udgiver mange forskellige formater og medieprodukter, kan man stille spørgsmålstegn ved, om de kan levere den ønskede diversitet i udbuddet af f.eks. nyhedsemner og vinklinger.

Som det er beskrevet ovenfor, så er ressourcerne sparsomme hos de grønlandske medier, og bliver økonomien på mediemarkedet dårligere, kan det sætte en begrænsning på antallet af medieudbydere eller medieudbuddet, hvilket kan mindske diversiteten. Det kan dog være, at den teknologiske udvikling kan åbne muligheder for forretningsmodeller, hvor økonomi ikke spiller så stor en rolle som hos de konventionelle medier. Det er nemlig blevet lettere og billigere at få medieindhold ud til en større befolkningsgruppe via f.eks. Facebook. I løbet af de seneste år er der etableret et par ikke-redaktionelle netmedier, der beskæftiger sig med Grønland. Som eksempel kan nævnes www.kamikposten.gl, der primært videreformidler uredigeret indhold såsom pressemeddelelser samt spørgsmål stillet af parlamentsmedlemmerne til Naalakkersuisut. I dag har ingen af disse netmedier ansat journalister eller modtager mediestøtte. Der kan derfor stilles spørgsmålstegn ved, om de kan bidrage til at levere kvalitetsjournalistik i fornøden grad; i hvert fald som det ser ud i dag.

\section{Kvalitetsjournalistik}

Angående konsekvenser af selvstændighed for sikringen af kvalitetsjournalistik, er særligt ét aspekt interessant at se nærmere på; nemlig danske mediers rolle i det grønlandske nyhedsudbud. Danske mediers historier om Grønland bliver citeret af grønlandske nyhedsmedier. Dermed udfylder den danske journalistik en demokratisk funktion i Grønland, som den muligvis ikke vil gøre, hvis Grønland opnår selvstændighed. For at undersøge størrelsen på dette bidrag for den grønlandske offentlighed er nyhedsindholdet i de grønlandske netmedier www.sermitsiaq.ag og www.knr.gl i perioden 1. juli 2017- 1. juli 2018 optalt. Gennem søgninger i Infomedia blev alle artikler fra www.sermitsiaq.ag og www.knr.gl, der refererer til landsdækkende danske medier, identificeret. Artikler, der ikke omhandlede grønlandske forhold, blev frasorteret. Derefter blev historierne i de danske medier, der refereredes til, identificeret (via Infomedia- og internetsøgninger). Da der her er tale om en mindre optælling, der kun omfatter de to redaktionelle netmedier i Grønland, kan dette betragtes som en eksplorativ undersøgelse. En undersøgelse af alle grønlandske medier ville givetvis give et andet resultat, da særligt TV og print anvender færre citathistorier (Ravn-Højgaard 2018a). Yderligere kan undersøgelsesdesignet ikke afdække, hvorvidt grønlandske nyheder er inspireret af historier i danske medier uden at referere til dem. 
Optællingen viste, at der i perioden var 177 nyheder fra www.knr.gl og www.sermitsiaq.ag, der refererede til danske medier og samtidigt handlede om Grønland. De refererede til 134 forskellige historier fra danske medier.

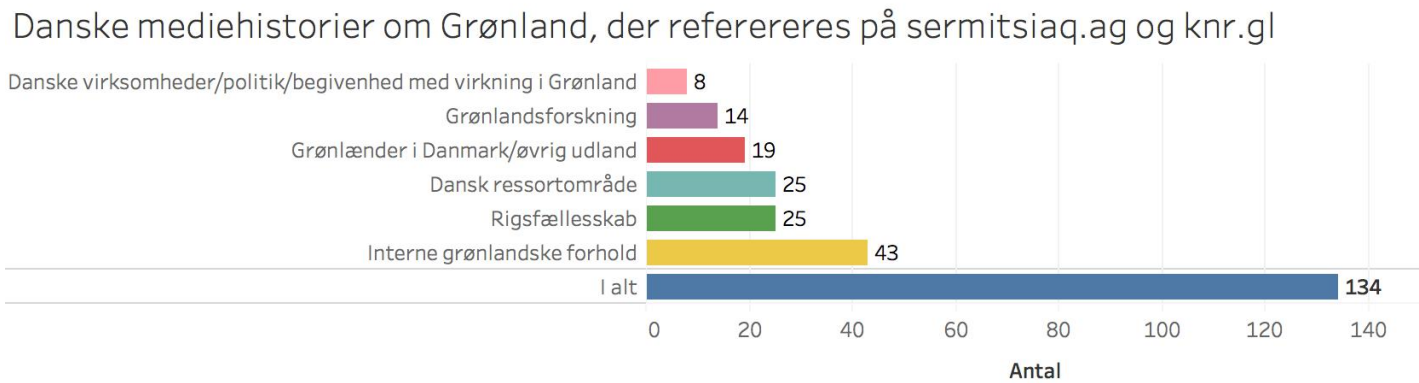

Figur 1: De forskellige danske mediehistorier om Grønland, som bliver refereret i grønlandske netmedier.

Som eksempel kan nævnes Dagbladet Politikens dybdegående historie om lange ventetider i kriminalsager, hvor børn skal videoafhøres i Grønland (Corfixen 2017). Historien blev efterfølgende taget op af de fleste grønlandske medier, hvor den blev viderebearbejdet med nye kilder og vinkler. Et andet eksempel er en historie fra DR, som på baggrund af en aktindsigt i Selvstyret afdækkede problemer med miljøvurderinger af mineprojekter (Frandsen 2017). Denne historie koblede AG sig på og viderebearbejdede den med selvstændig research (Lindqvist 2017).

Selvom det er ganske få af de 134 danske mediehistorier, der er resultat af så dybdegående research, så løfter danske medier nogle journalistiske historier med relevans for Grønland, som måske ellers ikke ville være blevet afdækket, hvis Grønland ikke var en del af Rigsfællesskabet. Dermed er den danske journalistik med til at udfylde en demokratisk funktion i Grønland.

Optællingen viste desuden, at 25 af de danske nyheder, som de grønlandske netmedier refererede, vedrører områder, der i dag varetages af rigsmyndighederne. I eksemplet med Dagbladet Politikens historie om videoafhøringer i politiet, blev historien til som led i en journalistisk satsning, hvor ventetiderne for videoafhøring i alle danske politikredse blev undersøgt - herunder også politikredsen i Grønland, som er en politikreds på linje med politikredsene i Danmark. De danske medier vil næppe producere denne type historier, hvis ressortområderne overgår til Grønland. Man kunne i stedet forestille sig, at de danske medier ikke i samme grad ville interessere sig for interne grønlandske forhold, men i stedet oftere nøjes med at referere grønlandske medier i historier om interne forhold, på samme måde som danske medier laver ganske få undersøgende historier om andre selvstændige stater, men i stedet refererer lokale medier. 


\section{Sprog- og kulturbevarende medier}

Sproget i de grønlandske medier kritiseres jævnligt. Det kan være antallet af grammatiske fejl, eller at det danske sprog spiller for stor en rolle i forhold til grønlandsk. Medierne bliver kritiseret for, at når meget af især nyhedsindholdet produceres på dansk og derefter oversættes til grønlandsk, så udvander det kvaliteten af grønlandsk i medierne (Frederiksen 2010; Grove 2010; Hansen 2017). Den underlæggende præmis for denne kritik er, at medierne spiller en vigtig rolle for bevarelsen og udviklingen af det grønlandske sprog. Dette er i tråd med forskning, der har vist, at medierne kan have en vigtig sprogbevarende funktion i små sprogområder (Pietikäinen 2008; Zabaleta et al. 2010). I debatten om sprogkvaliteten i medierne forklarer mediecheferne det manglende sproglige niveau med mangel på ressourcer og et dårligt skolesystem, der ikke har styrket journalisternes sprog tilstrækkeligt (Duus 2012a, 2012b; Hansen 2017). Hvis selvstændighed medfører dårligere medieøkonomi, kan det blive endnu sværere at afsætte de nødvendige ressourcer til at sikre den sproglige kvalitet.

Netop sproget i medierne bliver diskuteret meget, fordi sprog er identitetsbærende og grønlandsk identitet er tæt knyttet til det grønlandske sprog (se også Naja Carina Steenholdts artikel i dette temanummer). Da sprog derfor kan blive et emne med stort fokus i selvstændighedsdebatten (se f.eks. Gad 2017) og medier ses som havende en vigtig rolle i at styrke sproget i Grønland (Turnowsky 2017), kunne det således tænkes, at man fra politisk side vil regulere området anderledes end i dag og opprioritere mediernes sprogbevarende funktion i forhold til andre roller, som medierne skal udfylde i det grønlandske samfund. Denne regulering kunne ske ved at øremærke ressourcer til styrkelse af grønlandsk mediesprog.

Udover en sprogstyrkende rolle, kan medierne også have en kulturbevarende rolle i kraft af deres udgangspunkt i lokale emner, perspektiver og traditioner (Pietikäinen 2008). I den sammenhæng kan grønlandske medier noget som ingen andre medier kan; nemlig levere et grønlandsk perspektiv på verden. Det giver de grønlandske medier en særlig værdi, som udenlandske medieudbydere med langt større budgetter ikke kan tilbyde: medieindhold med Grønland som udgangspunkt. Selv hvis internettilgængeligheden og engelsk-kompetencer øges kraftigt, så er det ikke tænkeligt, at forbruget af grønlandske medier helt vil ophøre. De er jo de eneste medier, der beskæftiger sig med Grønland på grønlandsk. Dermed kan medierne også være et vigtigt instrument til at styrke grønlandsk identitet. I selvstændighedsprocessen kan medierne derfor blive tillagt en vigtig rolle som samlende og identitetsbærende.

\section{Konklusion}

Diskussionen om medier i et selvstændigt Grønland har her handlet meget om medieøkonomi og det offentliges rolle i det grønlandske mediesystem, for det grønlandske mediesystem er sårbart, og der er meget lidt økonomi i et så lille mediemarked. En meget stor 
del af mediernes indtægter kommer i dag fra det offentlige enten i form af mediestøtte, eller indirekte støtte $\mathrm{i}$ form af reklameindtægter. Selvstyret spiller derfor en vigtig rolle $\mathrm{i}$ at opretholde et medieudbud, der næppe ville kunne eksistere på markedsvilkår alene. Samtidigt gør dette også mediesystemet sårbart over for politisk pres. Derfor er det svært at forestille sig stærke medier i et selvstændigt Grønland uden en aktiv mediepolitik, der regulerer og subsidierer medierne.

Mediernes rolle er derfor i høj grad et politisk spørgsmål. Man kan forestille sig, at medierne får stor betydning $\mathrm{i}$ et selvstændigt Grønland, da de netop varetager nogle vigtige funktioner som at styrke det grønlandske sprog og levere journalistik om Grønland. I selvstændighedsprocessen kan det blive et politisk mål at skabe en særegen grønlandsk medie- og nyhedspraksis, som ikke er orienteret mod Danmark i samme grad som i dag, hvor grønlandske medier ofte citerer danske medier, hvor medielovgivningen ligner den danske og normerne om, hvad der er god journalistik, afspejler normerne i de danske medier (Hussain, udkommer 2019).

Denne artikel har taget udgangspunkt i, hvordan mediesystemet - som det ser ud i dag - kan tænkes at blive påvirket, hvis Grønland bliver selvstændigt, men selvfølgelig spiller mange andre faktorer ind på mediernes udvikling end blot selve Grønlands forfatningsmæssige status. For det første, spiller politiske beslutninger og udvikling på andre områder ind - f.eks. inden for teleinfrastruktur eller sprogpolitik. For det andet, påvirker globale tendenser det grønlandske medielandskab, selvom det sker lidt forsinket $\mathrm{i}$ forhold til resten af verden, blandt andet som følge af den begrænsede internettilgængelighed. Uanset om Grønland bliver selvstændigt, vil globaliseringen og den teknologiske udvikling komme til at påvirke det grønlandske mediesystem endnu mere, end det sker i dag. Medievanerne ændrer sig. Det er i dag især hos den yngre generation og i byerne, at vi ser, at forbruget af grønlandske medier falder, mens forbruget af netmedier og streamingtjenester stiger (Ravn-Højgaard 2018b). Samtidigt med at udviklingen giver nye muligheder for demokratisk deltagelse, og for at nye medier kan opstå, da det er let og billigt at publicere på internettet, kan det især for de private medier betyde fald i annonceindtægter, som i stigende grad tilfalder internationale aktører som Facebook og Google på bekostning af de grønlandske medier. Udviklingen kan på sigt kræve tilpasninger af formater, forretningsmodeller og produktionsmetoder hos de nuværende grønlandske medier, hvis de i fremtiden skal bevare deres relevans hos det grønlandske publikum. Det er dog hverken FM-båndet, som radioen udsendes på, eller papiret som avisen trykkes på, der har værdi for det grønlandske samfund, men derimod mediernes indhold. Her kan en fremsynet medieregulering være et element $\mathrm{i}$ at styrke de grønlandske mediers fortsatte relevans.

Uanset hvad, er det dog ikke sandsynligt, at befolkningen helt stopper med at anvende grønlandske medier. Grønlandske medier kan nemlig som de eneste i verden tilbyde indhold på grønlandsk og med et grønlandsk perspektiv. Derfor vil de grønlandske medier også være relevante for befolkningen i fremtiden trods hårdere konkurrence fra udenlandske medier med mange flere ressourcer end de grønlandske medier. 
Litteratur

AG (2011). Leder: Den fri presse. Atuagagdliuit/Grønlandsposten (uge 2, 19. January), s. 2.

AG (2015). Leder: Mediestøtte - derfor siger vi nej. Atuagagdliuit/Grønlandsposten (uge 43), s. 2.

Agneman, G. and Minor, K. (2018). Politik og klima - Den grønlandske befolknings syn på forandringer og fremtiden. Ilisimatusarfik. Tilgængelig på: https://da.uni.gl/arrangementer/2018-afholdt/december-afholdt/politik-og-klimaden-groenlandske-befolknings-syn-paa-forandringer-og-fremtiden-greenlandicperspectives-survey.aspx. [Tilgået d. 10. januar 2019]

Anderson, B. (1983). Imagined Communities - Reflections on the Origin and Spread of Nationalism. New York: Verso.

Bemoerkninger til Lov om Mediestøtte (2016).

Bestyrelsessekretariat (2018). Selvstyrets Aktieselskaber. Nuuk. Tilgængelig på: https://naalakkersuisut.gl/ /media/Nanoq/Files/Attached

Files/Bestyrelsessekretariatet/Redegoerelser/Årlig redegørelse for de selvstyreejede selskaber - DA 20181121.pdf. [Tilgået d. 10. januar 2019].

van den Bulck, H. (2001). Public service television and national identity as a project of modernity: the example of Flemish television. Media, Culture \& Society, årg. 23(1), ss. 53-69.

Corfixen, K. (2017). 165 dage gik der, før 10-årig pige måtte fortcelle politiet om overgreb. Politiken.dk. Tilgængelig på: https://politiken.dk/indland/art6158374 /165-dage-gik-der-før-10-årig-pige-måtte-fortælle-politiet-om-overgreb [Tilgået d. 15. juli 2018].

Deloitte (2018). Den Erhvervsdrivende Fond Sermitsiaq AG - Årsrapport 2017. (33). Tilgængelig på: https://datacvr.virk.dk/data/visenhed?enhedstype=virksomhed $\& \mathrm{id}=12539959 \&$ soeg=sermitsiaq \& type=Alle. [Tilgået d. 15. juli 2018].

Dollerup-Scheibel, M. (2015). Fagforbund: Store problemer med mediestøtten, Sermitsiaq.AG. Tilgængelig på: http://sermitsiaq.ag/fagforbund-store-problemermediestoetten [Tilgået d. 1. juli 2018].

Duus, S. D. (2012a). Journalister : Gør noget ved sproget i vores medier. Sermitsiaq.AG. Nuuk.

Duus, S. D. (2012b). KNR efter sprogkritik: Vi kan blive bedre. Sermitsiaq.AG. Nuuk. Tilgængelig på: https://sermitsiaq.ag/node/133343 [Tilgået d. 3. januar 2019].

Elkjær, K. (2018). Telepost-overskud sender 137 millioner kroner til Selvstyret. KNR.gl. Tilgængelig på: https://knr.gl/da/nyheder/telepost-overskud-sender-137-millioner -kroner-til-selvstyret [Tilgået d. 3. januar 2019].

Erhvervsstyrelsen (2019). Den erhvervsdrivende fond Sermitsiaq.AG, CVR-registeret. Tilgængelig på: https://datacvr.virk.dk/data/ [Tilgået d. 3. januar 2019].

Fleischer, K. (2008). Den grønlandske presse - en undersøgelse af pressens betydning $i$ forhold til den grønlandske nationsdannelsesproces 1979-2008. 
Frandsen, M. (2017). Fakta : Her er planen for uranminen i Grønland, Danmarks Radio. Tilgængelig på: https://www.dr.dk/nyheder/penge/fakta-her-er-planenuranminen-i-groenland [Tilgået d. 15. juli 2018].

Frederiksen, K. (2010). Sproget på nettet. I: Mediearbejdsgruppen (ed.) Stcerke medier. Nuuk.

Gad, U. P. (2017). What kind of nation state will Greenland be? Securitization theory as a strategy for analyzing identity politics. Politik, årg. 20(3), ss. 104-120. doi: 10.7146/politik.v20i3.97156.

Grove, A. (2010). Grønlandsk bliver tilsidesat i medierne. I: Mediearbejdsgruppen (ed.) Stcerke medier. Nuuk.

Hallin, D. C. and Mancini, P. (2004). Comparing Media Systems. Three Models of Media and Politics. Cambridge University Press, ss. 1-89. doi: 10.1080/1353712 0600745096.

Hansen, N. (2017). KNR om sprogbrug: Vi kan gøre det bedre, Sermitsiaq.ag. Tilgængelig på: http://sermitsiaq.ag/knr-sprogbrug-kan-goere-bedre [Tilgået d. 28. august 2018].

Hanusch, F. (2014). Dimensions of indigenous journalism culture: Exploring $\mathrm{Ma}^{-}$ori news-making in Aotearoa New Zealand. Journalism, årg. 15(8), ss. 951-967. doi: $10.1177 / 1464884913495757$.

Hussain, N. (2017). Bourdieu in Greenland: Elaborating the Field Dependencies of Postcolonial Journalism. I: Present Scenarios of Media Production and Engagement. Bremen: edition lumière, ss. 123-135.

Hussain, N. (2018). Medielandskabet i Grønland. I: Ravn-Højgaard, S. et al. (eds) Tusagassiuutit 2018 - en kortlogning af de grønlandske medier. Nuuk: Ilisimatusarfik.

Hussain, N. (udkommer, 2019). Journalistik i små samfund: Et studie af journalistisk praksis på grønlandske nyhedsmedier. Ph.d-afhandling, Roskilde Universitet.

Inatsisartutlov om mediestøtte (2016). Grønland. Tilgængelig på: http://lovgivning.gl/lov?rid=\%7B254FD782-9BED-4C0A-B460-

FBFDF727ED40\%7D. [Tilgået d. 3. januar 2019].

Inatsisartutlov om radio- og tv-virksomhed (2014). Grønland. Tilgængelig på: http://lovgivning.gl/lov?rid=\%7BA6AB3385-7387-4270-A5EE8D60D5CAF37D\%7D. [Tilgået d. 3. januar 2019].

Karlsson, R. (2008). Media and communication statistics. Faroe Islands and Greenland 2008. Nordicom.

Karppinen, K. and Moe, H. (2016). What we talk about when talk about "media independence"”. Javnost. Taylor \& Francis, årg. 23(2), ss. 105-119. doi: 10.1080/13183222.2016.1162986.

KNR (2014). Strategi og handleplan 2014-2017 - KNR-Puilasoq'. Tilgængelig på: https://knr.gl/da/om-knr/publikationer. [Tilgået d. 3. januar 2019].

KNR (2015). Public Service Kontrakt 2015-2018. Nuuk. Tilgængelig på: https://knr.gl/da/om-knr/publikationer. [Tilgået d. 28. maj 2019]. 
KNR (2018a). Arsregnskab 2017. Nuuk. Tilgængelig på: https://knr.gl/files/knr ukiumoortumik_naatsorsuutit_2017_kl-da.pdf.

KNR (2018b). Seer- og lytterundersøgelse 2017. Nuuk. Tilgængelig på: https://knr.gl/da/om-knr/publikationer [Tilgået d. 28. maj 2019].

Krarup, P. (2017). Frie medier er $i$ alles interesse - også magthavernes, Nordisk Journalist Center. Tilgængelig på: https://njc.dk/article/frie-medier-allesinteresse-ogsaa-magthavernes/ [Tilgået d. 28. maj 2019].

Lindqvist, A. (2017). Tryllede og truede sig til aktindsigtsafslag. AG Atuagagdliutit Grønlandsposten (3. Maj), ss. 6-9. Tilgængelig på: http://aviisi.sermitsiaq. ag/2017/05/01/ag_2017_18/[Tilgået d. 28. maj 2019].

Louw, E. (2005). The Media and Political Process, Media International Australia. doi: 10.1177/1329878x1013700130.

Lynge, F. (1998). Director General in a Period of Transition'. I: Rosing, P. F. and Marianne Stenbæk (eds) Radiormiut. Kalaallit Nunaata Radioa - Grønlands Radio - Radio Greenland 1958-1998. Nuuk: KNR/Atuakkiiorfik, ss. 227-228.

Mediearbejdsgruppen (2010). Stærke medier - Redegørelse fra mediearbejdsgruppen.

Naalakkersuisut (2018). Landskassens regnskab 2017. Tilgængelig på: https://naalakkersuisut.gl/da/Naalakkersuisut/Departementer/Finans/Landskasse ns-regnskab [Tilgået d. 25. august 2018].

Newman, N., Nielsen, R.K, Levy, D., Kalogeropoulos, A., og Fletcher, R. (2019) Reuters Institute Digital News Report 2018. Oxford: Reuters Instutite, Oxford University. doi: 10.1017/CBO9781107415324.004.

Nordlund, M. (2016). Facebook samler Grønland. Greenland Today, ss. 30-31. Tilgængelig på: https://issuu.com/greenlandtoday/docs/greenland_today_no_26. [Tilgået d. 28. maj 2019].

Pietikäinen, S. (2008). Broadcasting Indigenous Voices. European Journal of Communication. SAGE Publications Ltd, årg. 23(2), ss. 173-191. doi: $10.1177 / 0267323108089221$.

Puppis, M. (2009). Media regulation in small states. International Communication Gazette, årg. 71(1-2), ss. 7-17. doi: 10.1177/1748048508097927.

Puppis, M., D'Haenens, L., Steinmaurer, T. og Künzler, M. (2009). The European and global dimension: Taking small media systems research to the next level. International Communication Gazette, årg. 71(1-2), ss. 105-112. doi: $10.1177 / 1748048508097936$.

Ravn-Højgaard, S. (2018a). Indholdet i de grønlandske medier. I: Ravn-Højgaard, S. et al. (eds) Tusagassiuutit 2018 - en kortloegning af de grønlandske medier. Nuuk: Ilisimatusarfik.

Ravn-Højgaard, S. (2018b). Medieforbruget i Grønland. I: Ravn-Højgaard, S. et al. (eds) Tusagassiuutit 2018 - en kortloegning af de grønlandske medier. Nuuk: Ilisimatusarfik.

Schultz-Lorentzen, C. (2011). Mediebilledet kan krakelere. AG Atuagagdliutit Grønlandsposten (19. januar), ss. 4-5. 
Schultz-Nielsen, J. (2017). Selvstyret parat til at sælge ud af arvesølvet. Sermitsiaq.AG, (17. november). Tilgængelig på: https://sermitsiaq.ag/node/200858 [Tilgået d. 3. januar 2019].

Selvstyrets bekendtgørelse om medietilskud (2015). Tilgængelig på: https://naalakkersuisut.gl// /media/Nanoq/Files/Kundgoerelser/DK/2015/Beken dtgoerelser/bekg 19 DK.pdf [Tilgået d. 3. januar 2019].

Sermitsiaq (2018). Leder: Facebook. Sermitsiaq (21. september 2018).

Skovsgaard, M. and Dalen, A. Van (2017). Journalister $i$ Danmark. Syddansk Universitet. Tilgængelig på: http://danskemedier.dk/wp-content/uploads/countryreport-denmark-dansk-final.pdf [Tilgået d. 3. januar 2019].

Tele-Post (2017). Hurtigere internet til 80\% af landet | TELEPOST. Tilgængelig på: https://telepost.gl/da/nyheder/hurtigere-internet-til-80-af-landet [Tilgået d. 3. januar 2019].

Tele-Post (2018). Radiokcedeforbindelsen til Upernavik er klar. Tilgængelig på: https://telepost.gl/da/nyheder/radiokaedeforbindelsen-til-upernavik-er-klar [Tilgået d. 3. januar 2019].

Tele-Post (2019), Hvad betyder Mbit, Tusass. Tilgængelig på: https://tusass.gl/app/\#/products/private-internet-100 [Tilgået d. 3. januar 2019].

Telestyrelsen (2014) Vejledning om liberalisering. Tilgængelig på: https://naalakkersuisut.gl/ /media/Nanoq/Files/Hearings/2014/Vejledning til teleforordningens paragraf 2 om liberalisering/Documents/Vejledning til teleforordningens 2 om liberalisering DOK1614177 (4).pdf [Tilgået d. 3. januar 2019].

Thisted, K. (2018). En gift i blodet: Følelsesøkonomier i de dansk-grønlandske relationer. K\&K - Kultur og Klasse, årg. 46(125), ss. 71-94. doi: 10.7146/kok.v46i125.105544.

Turnowsky, W. (2017). Medier skal blive bedre til grønlandsk, Sermitsiaq.AG. Nuuk. Tilgængelig påt: https://sermitsiaq.ag/node/196777 [Tilgået d. 3. januar 2019].

Turnowsky, W. (2019a). Palle Jeremiassen kræver kriseberedskab af Tele. Sermitsiaq.AG, ss. 1-2. Tilgængelig på: https://sermitsiaq.ag/node/211448 [Tilgået d. 8. februar 2019].

Turnowsky, W. (2019b). Pele Broberg: Parlamentsdebatter skal - igen - sendes $i$ radioen. Sermitsiaq.AG. Tilgængelig på: https://sermitsiaq.ag/pelebrobergparlamentsdebatter-igen-sendes-i-radioen [Tilgået d. 1. februar 2019].

Zabaleta, I., Xamardo, N., Gutierrez, A., Urrutia, S., Fernandez, I. og Ferré, C. (2010). Between language support and activism: A complementary journalistic function among European minority-language newspeople. Journalism Studies, årg. 11(2), ss. 190-208. doi: 10.1080/14616700903290668. 